\title{
New Images in Old Frames: Ibn Harma (d. ca. 176/792) between Classical Poetry and Abbasid Modernity
}

DOI:

10.1163/22142371-12340023

\section{Document Version}

Final published version

Link to publication record in Manchester Research Explorer

\section{Citation for published version (APA):}

Smail Salhi, Z., \& Alqarni, H. M. (2016). New Images in Old Frames: Ibn Harma (d. ca. 176/792) between Classical Poetry and Abbasid Modernity. Journal of Abbasid Studies, 3(1), 56-89. https://doi.org/10.1163/2214237112340023

\section{Published in:}

Journal of Abbasid Studies

\section{Citing this paper}

Please note that where the full-text provided on Manchester Research Explorer is the Author Accepted Manuscript or Proof version this may differ from the final Published version. If citing, it is advised that you check and use the publisher's definitive version.

\section{General rights}

Copyright and moral rights for the publications made accessible in the Research Explorer are retained by the authors and/or other copyright owners and it is a condition of accessing publications that users recognise and abide by the legal requirements associated with these rights.

\section{Takedown policy}

If you believe that this document breaches copyright please refer to the University of Manchester's Takedown Procedures [http://man.ac.uk/04Y6Bo] or contact uml.scholarlycommunications@manchester.ac.uk providing relevant details, so we can investigate your claim.

\section{OPEN ACCESS}




\title{
New Images in Old Frames: Ibn Harma (d. ca. 176/792) between Classical Poetry and Abbasid Modernity
}

\author{
Zahia Smail Salhi \\ University of Manchester, U K \\ zahia.smailsalhi@manchester.ac.uk \\ Hussain Mohammed Alqarni \\ King Abdul Aziz University, Jeddah, Saudi Arabia \\ husmuh33@yahoo.com
}

\begin{abstract}
Classical Arabic sources generally refer to Ibrahim b. Harma (d. ca. 176/792) as one of the "last poets" whose poetry is quoted as lexical and linguistic evidence of sound and "unaffected" language, in other words "pure" Arabic. However, while we argue that the poet's "pure" Arabic is the main reason for his place of excellence in classical Arabic poetry, we suggest that the poet was well aware of the power of poetic imagery imposed by the new modernity experienced in the Abbasid era. Ibn Harma skillfully developed the new tool as a means of self-expression in a conscious search for poetic immortality. In this article, we aim to explore the poetic imagery of Ibn Harma through textual analysis of a selection of his poetry.
\end{abstract}

\section{Keywords}

Abbasid modernity - classical Arabic poetry - composite/partial image - Ibn Harma poetic imagery - self-image

\section{Introduction}

Poetic imagery is generally defined as sensory and figurative language used mainly to decorate, emphasize or illuminate certain meanings. The poet uses 
his own direct environment as a source or repertoire from which he draws images. These images are then used to express meanings that share certain qualities with the source object by means of insinuation. ${ }^{1}$ In such indirect manner, the poet often attempts to demonstrate his poetic skills and compete with his peers.

In the context of the classical Arabic literary tradition, poets often contended for innovation in the production of novel meanings through the construction of ground-breaking images. A poets' imagination allowed him to draw from novel sources for imagery while at the same time perfecting old meanings and images, adding new stamps inspired from new environments.

This article focuses on the Umayyad/early Abbasid poet Ibrāhīm b. Harma (d. ca. 176/792) who is considered by some as the last of the classical poets, by others as an early muhdath poet because of his using imagery alongside themes from classical poetry. ${ }^{2}$ In the Arabic literary tradition Ibn Harma is generally praised for being the seal of poets whose verses are cited as lexical and linguistic examples of pure Arabic. ${ }^{3}$ However, the abundance and diversity of imagery - particularly of self-depiction — found in his work have hardly been investigated and a close examination of his surviving poetry reveals that it is, in fact, predominantly literary and rhetorical rather than just a set of linguistic and lexical prototypes.

In this article, we argue that Ibn Harma sought poetic immortality by expressing his own personality and individuality by means of opulent and versatile poetic images. Ultimately, he succeeded in being recognized as an excellent poet by scholars of his own time and of later periods, who quote his most striking imagery and memorable verses.

Although Ibn Harma's complete original dīwān has been lost, his poems are found scattered throughout numerous Adab anthologies, ${ }^{4}$ and they have been

1 See for a general definition of imagery, for instance, Encyclopcedia Britannica Online (Poetic imagery); more specific, The New Princeton Encyclopedia of Poetry and Poetics (Metaphor); in Arabic literature, The Routledge Encyclopedia of Arabic Literature (Imagination; Metaphor).

2 Cf. Toorawa, Ibn Harma. For the scarce information about Ibn Harma's life and works, see Pellat, Ibn Harma; Sezgin, GAS, II, 444-5; Blachère, Histoire, 538-9; Stetkevych, Early Islamic Poetry, 380 (quoting al-Jāḥiz from Bayān, I, 50-1: “... there is no one among the Moderns better in bad̄̄ than Bashshār and Ibn Harmah”); Toorawa, Ibn Harma (“... is the last poet mentioned in Abu Tammām's anthology, al-Ikhtiyār al-qabä̀ilī”).

3 Cf., for instance, Jabal, Ihtijajj bi-l-shi'r, 80-1.

4 See, for example, Ișfahānī, Aghānī, IV, 257-276; Ibn Qutayba, Shi'r wa-l-shu'arā̄, II, 753-754. Some of his longer pieces are quoted in full as, for instance, in Jāhiz, Hayawān, vi, 126-7, where his poem "On the Lizard and the Frog" is cited completely. 
collected twice from these sources in the twentieth century. ${ }^{5}$ In what follows, we analyze a selection of Ibn Harma's surviving verses and examine the poetic tools he employed to construct poetic images and imagery in order to establish his position between the rear-guard of the classical poets and the transition to Abbasid modernity. First, however, we briefly discuss Ibn Harma's distinctiveness in the broader context of classical Arabic poetry.

\section{Ibn Harma's Individuality}

Ibn Harma's attempts to develop specific poetic tools to express his individuality and to build up a repertoire of distinctive poetic imagery are best understood in the socio-historical context of professional poets, like Ibn Harma, who were above all seekers of material rewards from their patrons. Composing panegyrics was the profession of poets in Ibn Harma's time and the search for distinctiveness took place within a rivalrous community of poets and patrons. Many examples indicate Ibn Harma's intention to distinguish himself from other poets, but the most obvious distinguishing feature is his poetic imagery, especially the images in which he depicts himself. Although of less significance, a few other peculiarities of his poetry are worth mentioning.

A clear instance of Ibn Harma's search for distinctiveness is an anecdote found in al-Suyūțī's Sharh shawāhid al-Mughnī. ${ }^{6}$ It is reported that when Ibn Harma was told that in his own tribe, the Quraysh, poets would not use the letter hamza, he defiantly replied, "then I shall compose a poem using the hamza in the tongue of Quraysh." He subsequently composed a poem rhyming with hamza. He may have not been the first to do so, it nevertheless expresses an explicit desire to sing outside the flock and to convey the message that he could be an innovator.

Another indication of Ibn Harma's determination to prove his uniqueness is the composition of a poem of forty verses using only the un-dotted letters of the Arabic alphabet. Only twelve verses of this poem have survived, but the

5 Muhammad Jabbār al-Mu'aybid published a collection of Ibn Harma's poetry in Dīwān Ibrāhìm b. Harma in 1969 and in the same year, Muhammad Naffā' and Husayn 'Ațwān published a collection in Shi'r Ibn Harma, Ibrähìm b. 'Alī al-Qurashī. The first collection, though a solo effort by al-Mu'aybid, contains far more verses and is meticulously organized with thorough text editing, which makes it superior to the second collection. The present study, therefore, relies basically on al-Mu'aybid's collection with references to the Naffā' and 'Ațwān-collection (freely accessible online) where appropriate.

6 Suyūṭī, Sharh shawāhid, 826; cf. Mu'aybid, Diwān, 48; Naffā' and 'Ațān, Shi'r, 55 . 
original version seems to have been longer. ${ }^{7}$ In the context of tracing types of rhetorical ellipsis using un-dotted words throughout a whole poem, AbuKhadra discusses this poem of Ibn Harma at length (albeit to establish whether or not he was the first to compose such a poem). ${ }^{8}$ Although one can tell from the few verses that this poem is stiff and artificial compared to the poet's usual style, it shows Ibn Harma's desire to stand out as unique and distinctive.

What remains of Ibn Harma's poetry was preserved not only because of its uniqueness, but reportedly also because of its value as lexical and linguistic evidence of "pure" Arabic. The predominance of references to Ibn Harma in literary and rhetorical works over linguistic and lexical studies suggests, however, that he was mainly of interest to authors of literary books. This questions the linguistic significance as being the only reason for the place and admiration his poetry has achieved in classical Arabic sources.

Unfortunately, most of Ibn Harma's surviving poetry is fragmentary and so it is difficult to assess the character and quality of his work as a whole. As 'Adnān Husayn Qāsim maintains, appreciating poetic experience and its function cannot be achieved without realizing the images in their context. Since images do not function in isolation from context and are imposed by poetic and emotional experiences of the poet, "we can say that the essential artistic method to transfer the experience is the image."

However, in circumstances like those pertaining to Ibn Harma's poetry, two methods seem to be appropriate in evaluating poetic images: on the one hand a study of subject matter divided into categories - such as people, animals and nature; on the other an analysis of how they are structured. While the first method helps evaluate the nature and extent of Ibn Harma's inventiveness in creating new images, the second furthers an assessment of the contribution of images to the artistic power of his poetry and his ability to distinguish himself from his contemporaries and even from earlier classical poets.

The poetry of Ibn Harma includes images of people, animals, nature, and the various conditions of life encountered by any person. Surprisingly, a large number of these images are self-images, which seems to indicate the poet's ambition and his determination to attract his audience's attention to the value of his poetry, and hence the value of the poet. On many occasions Ibn Harma

7 The verses are found in Ișfahānī, Aghānī, IV, 264-5. Both the Mu'aybid (Diwāan, 179-181) and the Naffā' and 'Ațān (Shi'r, 175-8) editions have these twelve verses in the same order, but the latter edition has inserted dots after the tenth line to indicate some missing verse or verses.

8 Abu-Khadra, Ellipsis; the poem is called Awașlu Sawdah amsā dāris al-țalali.

9 Qāsim, Tașwìr shi'rī, 247. 
refers proudly to his poetic abilities and to the high and valuable quality of his poetry. He also often refers to his noble qualities and fine traits presenting himself as an honorable man with all possible virtues. But he is not to be believed - the real nature of the poet, his life or his poetry is not truly reflected in his verses, because

... the physical and moral portrait of Ibn Harma is scarcely an attractive one. Ugly, small in stature, importunate and avaricious he was furthermore addicted to drink, a vice which earned him some disappointments. ${ }^{10}$

However, according to the Andalusi literary theorist of the seventh/thirteenth century, Hāzim al-Qarțājannī, the beauty of poetry lies in creating an imagined image which is more beautiful than reality, making things look more attractive than they are in real life. ${ }^{11}$

\section{Thematic Analysis of Ibn Harma's Imagery}

\section{Self-Images}

A person's self-image is often defined as the conception or the mental image one has of oneself and as the image one projects about one's own self. This image, however, is not purely based on an evaluation of one's self-worth, but it is an amalgam of many factors such as how an individual sees one's self, how others see the individual and how the individual would like to be seen by others. In other words, the self-image an individual produces and projects may or may not be accurate.

In classical Arabic poetry, poets used self-images to emphasize Arabian traits that were imbedded in Arabic culture - such as generosity, self-esteem, satisfaction and contentment, patience and endurance, poverty (especially in the context of panegyrics) - and to describe personal feelings about love experiences, grey hair and vanished youth, or adoration of wine. Additionally, a poet may write about his loyalty to people, especially politicians, and his tolerance, even of his enemies.

Furthermore, through his poetry a poet would praise his own poetic skills and abilities, and his status, practice and ideals as a poet, which seems to

10 Cf. Pellat, Ibn Harma, perhaps relying on Ișfahānī, Aghānī, IV, 258-260. Al-Mu'aybid (Diwān, 15-8) also describes the poet's life and personal habits, his behaviors and values, as in complete opposition to the way the poet depicts himself.

11 'Ușfūr, Șūra faniyya, 409-410. 
indicate that he is trying to define himself and project his self-image through his poems. As Pamela Annas defines,

a poem is a stage in the process of self-definition, a grounding and realizing of self-image and image of the world... The form of the poem is an expression of everything that the poet is, and is expressing. ${ }^{12}$

In order to evaluate Ibn Harma's artistic achievements and ethical stance, we will now discuss some of the self-images he constructed. Although many of his self-images sound like typical fakhr, "boast," common in Arabic poetry from all eras, a closer look at his surviving poetry reveals a particular way, a specific twist in most images of his creation bearing a very personal stamp.

A highly valued attribute in Arabic culture is self-restraint. As Ibn Harma puts it: ${ }^{13}$

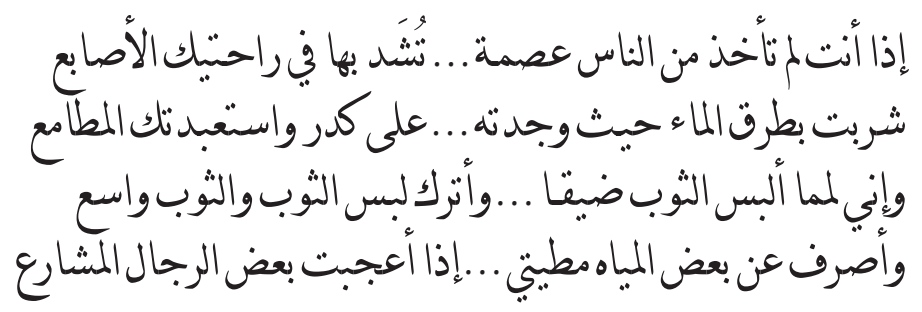

If you do not adopt self-restraint with people, holding your fingers strongly in your palm

You will drink whatever turbid water you may find, becoming thus a slave to your rapacity

It is thus why I sometimes would wear tight clothing, although loose garments may be at hand

And I would not allow my mount to drink from some water sources, though many folks would like them

12 Annas, Poetry of Survival, 9-25.

13 Mu'aybid, Diwāan, 140; in the Naffā' and 'Ațwān edition (Shi'r, 140-1), the third verse is omitted and a new verse is added after line 4 (wa-așrifu ...) ; this is contrary to the source from which the verses are quoted (cf. Buhturī, Hamāsa, 26o-1). Moreover, this reattachment is wrong leaving the poet committing a basic error in prosody, that is, it makes him repeat the word al-mațāmic within three lines, whereas the canon of prosody prescribes to use the same word as the word of rhyme ( $q \bar{a} f i y a)$ only after a minimum of seven verses with different rhyming words have been written. 
The image of clenching one's fist emphasizes the poet's self-restraint and feeling of independence, the condition of being internally strong. Other images based on metaphor are choosing to wear tight clothing although loose garments are at hand, and refusing to drink turbid water and not permitting a horse to quench its thirst.

Such images depict the poet's self-esteem in preferring honest poverty to unworthy wealth. The first two lines are presented in the form of advice to himself and possibly to his audience. The last two lines clearly intend to portray his persona as a model of self-restraint willing to overcome worldly temptations. The poet thus enhances his self-image in the eyes of his audience.

A similar display of images of self-esteem is found in some verses employing the image of a water source to convey a positive self-image, as in the following lines: ${ }^{14}$

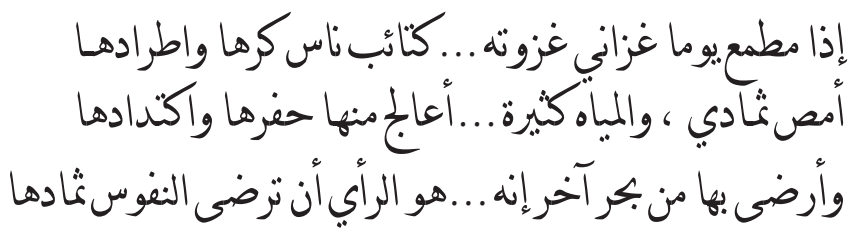

If someday greed invades me I would invade it, like brigades attacking and pursuing

Hence, I lap up shallow water, struggling, by digging and extracting, though there is much water elsewhere

But I am satisfied with mine instead of the sea of another, as it is true wisdom to satisfy the self with its own shallow water

Again, the poet enhances his self-image as an honorable man satisfied with his own resources and following the "true wisdom" of self-sufficiency and independence, even if this means a life of poverty and struggle. Inasmuch as the poems in the diwwan are not dated, the historical order of composition of the two fragments is unclear. However, the intensity of the imagery in the second example suggests that it has been composed later than the first.

The theme of endurance is also found in Ibn Harma's self-images used to depict live experiences, as in: ${ }^{15}$

\footnotetext{
14 Mu'aybid, Diwān, 97; Naffā' and 'Ațwān, Shi'r, 113-114.

15 Ibid., 58-59; ibid., 68-69.
} 


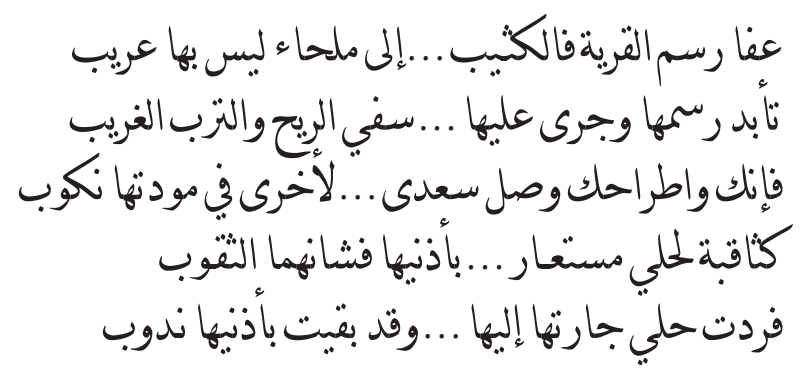

The traces of al-Qurayya, al-Kathīb and Malhạà have vanished, with no human life on them ${ }^{16}$

The traces, because of the dusty wind and the sand blown from afar, have become a mere wilderness.

You are, by leaving the love of Su'dā and replacing it with the love of another, whose love is not gracious or lasting

Like a girl, who has her ears pierced for borrowed earrings, but afterwards disliking the piercing

She returns the earrings to her neighbor, but the scars of the holes remain in her ears

Although Ibn Harma explicitly refers to another person, he is describing his own self as he endures the consequences of leaving his first beloved Su'dā, whose love was constant and lasting, whereas the love of the second beloved is far from being on a par with the first. By this action the poet lost the love of both, the first willingly, the second grudgingly. Ibn Harma's proud self-image is replaced by one of self-criticism and remorse, as emphasized by the powerful simile in verses four and five.

\section{Images of Other People}

The images of other people in Ibn Harma's poetry are of those with whom he has connections or relationships, especially beloved women and worthy patrons. The poet creates many images of beloved ones using different names — such as Su'dā, Salmā, 'Ulayya, Asmā' and Hind. These names may not refer to real loved ones, or they may be different names for one woman. In his study of the mythological meanings of the artistic image in pre-Islamic poetry, Nușrat 'Abdul-Rahmmān suggests that such names stand as symbols for the "Lady of Wisdom" and that the pre-Islamic poets tended to call upon her in

16 Al-Qurayya, al-Kathīb and Malhāà are the names of the beloved's deserted camps as they appear in the classical tradition of nasīb. 
"the important matters which need carefulness and patience." ${ }^{17}$ However, Ibn Harma followed the style and structure of the traditional qasida and it seems that the names of these women are mainly used for the purpose of fulfilling the requirements of the introductory part (nasib) of the classical poem. Although the identity of the woman/women is uncertain, the images of the beloved need to be analyzed in order to assess the poet's methods.

\section{Images of the Beloved}

The images of the beloved have diverse motifs: the poet not only refers to parts of her body such as her hair and eyes, but he also depicts her smell, apparition, characteristic behavior such as aloofness, and different aspects of her relationship with him. It is noteworthy that almost all of Ibn Harma's images of the beloved are to be found in the context of the nasib - except for a few that appear in the short surviving fragments - so their contexts and significance for the poem as a whole cannot be determined.

Some examples of these images nevertheless show his style in depicting the special features he attaches to his beloved. The following lines describe the effect of an apparition visiting the poet during the night: ${ }^{18}$

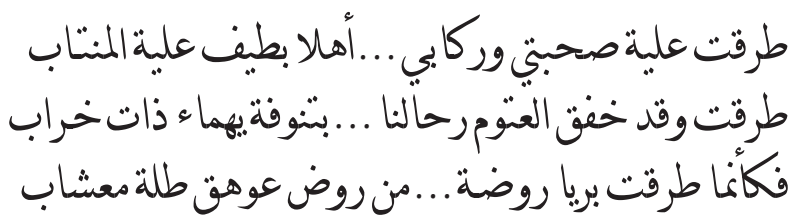

'Ulayya's specter has come to me at night while sitting among my friends and our mounts; oh you are welcome 'Ulayya's recurrent specter

She came when the darkness laid its cover on our camp, pitched in the midst of the desert wilderness

It was as if she brought a drizzling meadow, from the dewy and grassy meadows of 'Awhaq

The poet depicts what he imagines whenever the memory of his beloved 'Ulayya comes to his mind while sitting in the dry desert with his friends and among their camels. His thought of her manages to transform the barren desert into a dewy green meadow, and because of this change produced by his imagination he addresses her visiting specter, welcoming it. The poet employs the elements of the desert and the darkness, the social gathering of himself

17 'Abd al-Raḥmān, Șūra fanniya, 146.

18 Mu'aybid, Diwān, 66; Naffā' and 'Ațwān, Shi'r, 72-73. 
and his friends and their mounts at night, and puts them alongside a dewy grassy meadow to depict the wonderful effect of the apparition. ${ }^{19}$

Ibn Harma employs elements that can be perceived by the senses, such as the night, the desert, friends and camels, and introduces into this setting a psychic image, the imagined apparition of the beloved. He does the same in another imagination of the beloved, but here he foregrounds the sense of smell: ${ }^{20}$

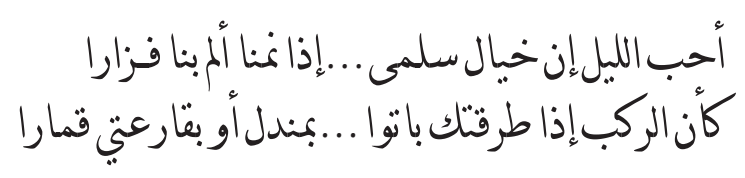

I love the night because the apparition of Salmā comes to visit us when we are about to sleep

It is as if the assembled company has slept in Mandal or on the edges of Qamār

Mandal and Qamār are places in India believed to be the sources of the very best Indian Oud, a fine incense that gives a pleasant fragrance. ${ }^{21}$ So, here the poet compares the effect of his beloved's apparition with a fragrance of the finest incense that transports him and his companions to India where they spend the night.

\section{Images of the Patron}

Generally, the patrons praised by the poet are governors, political leaders, and caliphs. All of them are bound to be rich, as the poet nearly always refers to their wealth, generosity and nobility. These motifs are commonly used by poets to emphasize a patrons' honesty, bravery and glorious achievements, but, more importantly, his generosity, since their desire for a reward of money is above all else.

Depending on the circumstances, Ibn Harma employs different methods in seeking to extract this reward. He sometimes adopts a direct approach praising the generosity of the patron who undoubtedly will respond with a gift of money. Other times, however, the poet may be disappointed by his patron and then he uses indirect methods. He even goes so far as to insult a patron who

\footnotetext{
19 For more about types and functions of the phantom and apparitions in classical Arabic poetry, see Jacobi, The Khayāl Motif; Sells, Guises of the Ghūl.

20 Mu'aybid, Diwān, 110.

21 As explained by al-Mu'aybid, Diwān, 110.
} 
has not rewarded him, unmoved by his praise. This is, for instance, the case with the grandson of 'Alī b. Abī Ṭālib's brother, Mu'āwiya b. 'Abdallah b. Ja far, whom he addresses in the following lines: ${ }^{22}$

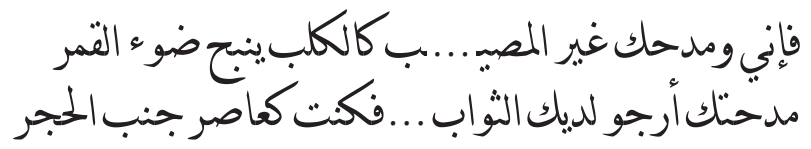

I wrongly gave praise to you, like a dog barking at the moonlight Seeking reward from you through my praise, was squeezing water from a dense stone

The images of the patron, who is likened to the indifferent moonlight in the first verse and to a stone in the second, express the poet's feelings of disappointment. It seems likely that the poet has made several attempts to win the patron's favor, all without success, thus comparing himself to a dog trying to get noticed by the moon, and the patron to a dense stone from which it is impossible to extract water. Usually images of the moon are positive, but in this instance Ibn Harma brings up the moon as a distant, indifferent and cold moon whose shining beauty mocks the dog's efforts.

Ibn Harma seems to have been well aware of the images his prospective patron would like to hear and to have been able to cater for his requirements. This clearly appears from an anecdote related by Ibn 'Abd-Rabbih about a number of poets who were waiting at al-Manșūr's palace gate for permission to enter and praise the caliph. Al-Manșūr sent his usher to command the poets as follows: ${ }^{23}$

Whoever wants to praise me must not depict me as a lion, because the lion is a dog among dogs; not as a serpent because it is a rotten beast eating dirt; not as a mountain because it is a solid rock; not as a sea because it roars and has tidal waves. So if anyone intends to include these in his praise of me, he is advised to leave." Hence they all left except Ibn Harma, who exclaimed: "I am the one for him," and when he entered, the caliph said to his usher: "I knew that he alone would respond to you."

\footnotetext{
22 Mu'aybid, Diwān, 109.

23 Ibn 'Abd-Rabbih, Iqd, I, 262.
} 
The following analysis of one of the poems in praise of al-Manșūr sheds light on the patron's image and place in Ibn Harma's poetry: ${ }^{24}$

1- Proud youth has removed its garments from you, and the beloved, on the point of leaving, has bid farewell 25

2- To you, oh prince of believers, the camels have brought us through the deadly extensive deserts

$3^{-}$To visit one whose affairs are not resolved by others, to whose advice he needs not pay attention

4- If he refuses a thing then it is over, and if he says "I will do it" then it is done

5- He is generous, having two faces: the first is jovial in secure achievements, and the other is intrepid in difficulty

6- He does not forgive without being able to punish, he forgives when he has power to order demise

7- He casts glances around his throne, and those glances convey punishment and hope

8- The mother of the one to whom you have given safety is safe, and the mother of the one you have threatened is bereaved

9- We come to you bringing a need and a means, as wishes are sure to be fulfilled by you

10- Remembering the cordiality that God has long strengthened between us and has not been harmed by the malice of others

11- I swear that your kindling flint has never disappointed anyone, and the hope the midwives put in you was not false

12- And that no one in need has been prevented from petitioning you by any excuse, and your immediate gift has not stopped the giving of a later one

13- And that the poor petitioner has not blamed himself for asking you, and parsimony has never judged your generosity

24 Mu'aybid, Diwān, 166-169; Naffā' and 'Ațwān, Shi'r, 166-170. See the original Arabic text in Appendix 1. Fragments of poems exceeding seven verses are quoted in full in the Appendixes; smaller fragments are cited in the main body of the text.

25 The Naffā' and 'Ațwān edition has a line before the first line which reads as follows: 'Afā al-nafu min Asmä’ naffu rawāwatin ... Fa- Rïmun fahaḍbu al-muntazāa fa-l-saläilu. In this line, the hemistiches do not rhyme $\left(\operatorname{tassr} \bar{l}^{\top}\right)$, unlike the hemistiches of the first line in al-Mu'aybid's edition (... al-mutakhāyilu ... al-Muzāyilu). It is just one of many examples where the editors attach two or three short segments to a poem just because they share the same prosodic meter (wazn) and similar rhyming letter (rawiy). 
14- You are from the white clay, from the Āl Hāshim, whereas the tribes' meanness blackens their clay

15- I have not seen you deviate from the path of justice, and your fairness has not been disrupted by your other concerns

Although the motifs of praise in this poem are not Ibn Harma's own invention, the images with which he enlivens them have a unique and personal stamp in the way they are skillfully fashioned. Verse (1) is a good example in that it refers not to the caliph but to Ibn Harma himself - youth departs taking its garments and with it, the beloved departs as well.

Ibn Harma's composition is clearly in accordance with al-Manșūr's command. The praise verses (2-15) intend to please the caliph and there are no extravagant metaphors or comparisons with powerful animals (as, for instance, a herd of camels in a poem that will be discussed shortly). The caliph's power, justice, wisdom, and generosity are praised in a relatively plain style.

Verse (14) contains an interesting metaphor justifying the Abbasid claim to the caliphate by reference to the "white clay" in al-Manșūr's possession, referring to the purity of his family connection with the House of the Prophet. The clay refers to the human race, a notion found in the Qurān to denote the beginning of human existence. ${ }^{26}$ The image of the clay is therefore not an original creation of the poet.

The entire image of the caliph is constructed from partial images (a subject that will be discussed in more detail below), notably that of the never-failing flint that kindles fire, vital for the well-being of his people, the midwives' fulfilled hope and the purely abstract image of the parsimony which has never judged the caliph's generosity. The references to generosity are, needless to say, prompts to al-Manșūr to pay handsomely for the poet's services. The various images show the poet's intention to please the caliph and obtain a welldeserved reward, but they reveal his determination to avoid criticism or, even worse, anger of al-Manșūr who has forewarned him to avoid certain images.

Although Ibn Harma's connection with the muhdath ("modernity") project is much clearer in his use of strong imagery in general and more particular the metaphor, the poem for al-Manșūr shows similarities with muhdath poetry. This similarity comes also to light in the shortening of the introductory section of the poem (nasib). In some cases, this section is even completely discarded, as the famous representative of the muḥdath poets, Abū Nuwās (d. 200/815), used to do, replacing the opening verses with lines about the beauty of wine.

26 See, e.g., Q 32:7. 
As such, Ibn Harma seems to present with this poem an early example of a changing attitude towards the structure of the classical ode. ${ }^{27}$

\section{Images of Animals}

The animal-theme in Ibn Harma's images occurs in different contexts; some of them are imitative, others seem to be invented by the poet himself. The image of the camel in the nasib of the traditional poem is frequently employed by poets as a compulsory motif, but Ibn Harma brings something new to this wellworn image. In the praise section of his poems he sometimes creates a striking camel-image depicting the relationship with his patron, as in:28

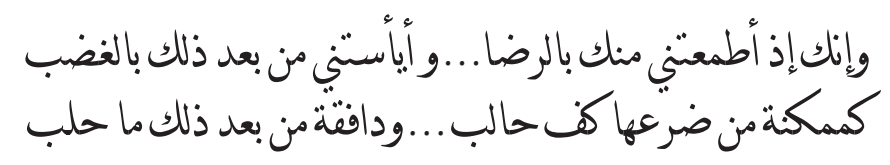

You are, by driving me to desperation through your anger, after driving me to covetousness through your gratification

Like the she-camel which allows the milkmaid to fill her bowl, then kicks over the container, spilling what she has milked

An examination of the poet's usage of the camel-motif in general indicates that Ibn Harma usually presents the camel to depict positive ideas. Indeed, part of this image may indicate the poet's appreciation and love of camels. Here the poet is employing the image of the camel in the praise section, according to the order of the traditional poem the last section of the poem. However, it is remarkable that Ibn Harma uses the animal image not to praise, but to insult his patron.

A similar motif in the tradition of the classical poem is the image of the dog. Notably out of poetic context, likening people to specific animals, particularly the dog and the donkey, is rather insulting in Arabic culture, even today. However, some positive uses of animal motifs can be found in classical poetry as early as the pre-Islamic era. The renowned poet of the Jāhiliyya, al-Nābigha al-Dhubyānī, for example, uses the dog motif in a positive manner when he

27 On metaphors in muhdath poetry and the desire for inventing new ones (isticāāat), see Heinrichs, Paired Metaphor. See Stetkevych, Zephyrs of Najd (especially the chapter on Arabic Elegiac Lexicon) for a discussion of types and functions of the nasīb in classical odes.

28 Mu'aybid, Diwān, 55. For a discussion of camels in the nasīb, see Jacobi, The CamelSection; and ibid., Time and Reality. 
depicts a hunting scene. ${ }^{29}$ Likewise, Ibn Harma uses the image of a dog to praise himself and his own generosity, as in the following lines: ${ }^{30}$

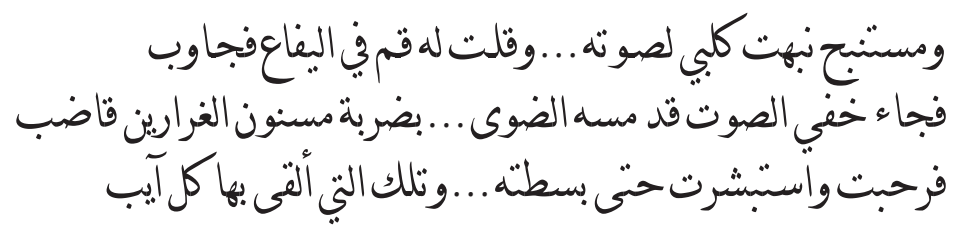

A hungry man was making a barking sound hoping to be rescued;31 I awoke my dog to respond to the sound he was making and I said: Climb the hills and answer him

So, a man came weak-voiced, as starvation had stabbed him with a very sharp sword

Rejoicing, I welcomed him until he was satisfied, and this is my habit with which I meet every guest

The poet's depiction of his own generosity is raised above the level of the mundane by the personal and humorous device of the interaction between the poet and his dog, bringing the scene to life and stimulating the audience's imagination. A similar immediacy is found in a fragment where the dog again takes the main role, though it is not clear (as the poem is incomplete) whose generosity is being praised, the poet's or the patron's - most probably that of the former: ${ }^{32}$

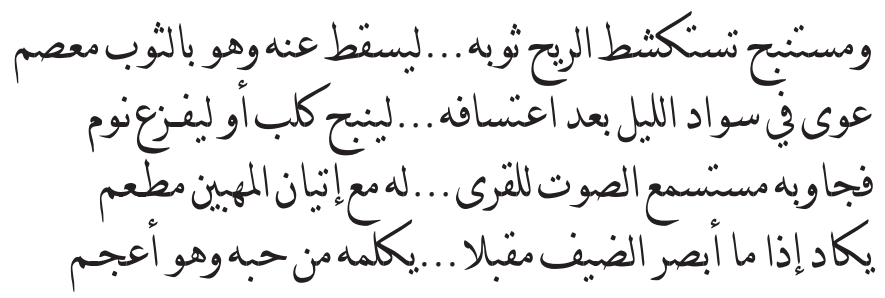

29 Bashīr, Șūrat al-nāqa.

30 Mu'aybid, Diwān, 64.

31 The barking sound (mustanbih) is the sound someone lost in the desert makes in the hope that a dog hears, so that his master comes to the rescue.

32 Mu'aybid, Diwān, 208. The fragment consists of four lines in the Mu'aybid-edition; the Naffā' and 'Ațān-edition has eight lines because extra lines were taken from other sources. 
A hungry man is making a barking sound, while he fearfully clings to his garment of which the howling wind is unabatedly stripping him off He cries out at night's darkness, being lost, trying to make a dog respond to his barking sound or to awaken a sleeping soul

The dog was eagerly waiting for the calling sound, as such a visit would bring it a copious meal

So when it sees a guest coming, the dog almost talks him in with much love, though it is dumb

The poet seems to be depicting his own generosity but the dog is the main actor in this small scene. This is a development from the previous poem in which the dog is asleep and the poet awakens it and tells it to answer the call of the hungry traveler. In this second example, the dog itself is awaiting for the barking sound made by a hungry caller, as his master's welcoming of the guest will bring him food, perhaps as a reward for rescuing a lost and hungry traveler who will satisfy the poet's desire to show his generosity.

The dog's reward occurs in another context, where the poet mentions that dogs become happy as the host gives them pieces of the hump when slaughtering a camel to feed the guest. ${ }^{33}$ This supports the assumption that the poet is employing the image of the dog as a motif in building his self-image as a generous host, a highly valuable attribute in Arabic culture.

\section{Images of Other Natural Elements}

Elements of nature other than animals are often found in Ibn Harma's poetry as well, not only as repeated themes but also as deliberately innovative motifs. The image of the desert or the homeland of the beloved frequently appears as a motif in the nasīb of the traditional poem. Although Ibn Harma generally follows the structure of the traditional qasida in composing a nasīb, he sometimes composes an introduction that reflects his taste and desire to be different. The poet's contribution to innovations within the form of the traditional poem seems to be made by adopting a different approach to the content of the nasi $\bar{b}$. Instead of the traditional elements which emphasize the harshness of the desert environment, Ibn Harma transforms the sterile wilderness. For example, images found in any traditional poem ${ }^{34}$ are replaced by those of palms, doves and rain, making the desert bloom with life: 35

33 Ibid., 61.

34 Like, for instance, Imru' al-Qays's mu'allaqa/ode; cf. Awaḍ, Qașìda, 181.

35 Mu'aybid, Diwān, 76-77; Naffā' and 'Ațān, Shi'r, 80-81. 


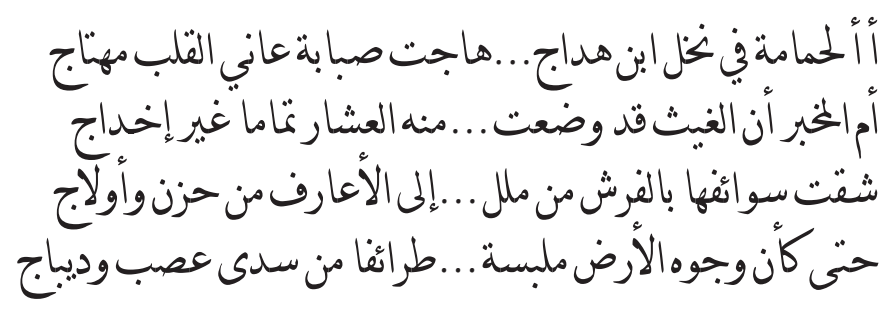

Does the dove in the palm-trees of Ibn Haddāj prompt the yearning of a heart desperate and in pain?

Or does the messenger tell that the ten-months-pregnant rain clouds have given birth rightly and at full term?

That the sand, hills and valleys from al-Farsh of Malal to al-A'ārif have all become full of grass

It is as if the earth's faces have put on a uniquely ample garment of embroidered silk

In the traditional poem the desert wilderness of the beloved's homeland is the motivation of the poet's longing and sadness, but Ibn Harma's longing is prompted by the life of the palm-trees and the dove's cooing and the sight of the living earth's surface after heavy rain in what seems to be a lush oasis. The passage demonstrates the poet's ambition to create new alternative images and, in consequence, to show himself worthy of a high rank among his peers.

The objection could be made here that the poet is merely replacing the subjects of the classical poem with "modern" or unusual ones, which would not constitute a true innovation. Be that as it may, Ibn Harma's surviving poetry contains many fairly long passages in which the subject matter is innovative. For example, one twelve-verse fragment, which seems to be complete as a section, describes the stars (nujūm). Although poetry on astrological themes became very popular and rather controversial in the Abbasid period, Abū Ṣâlih seems to be right in saying that the images in these verses are rather descriptive, each verse describing a star by means of a simile. ${ }^{36}$ See, for instance, the following lines: ${ }^{37}$

36 Cf. Abū Șāliḥ, Ibrāhīm b. Harma, 351. For more details on astrology in the medieval period, see Abbasi, Astrology in Literature; also Salhi and Al-Abbasi, Astrology between Poetics and Politics.

Mu'aybid, Diwān, 114. An interesting discussion about these stars can be found in Marzūqī, Azmina, 436-437. 


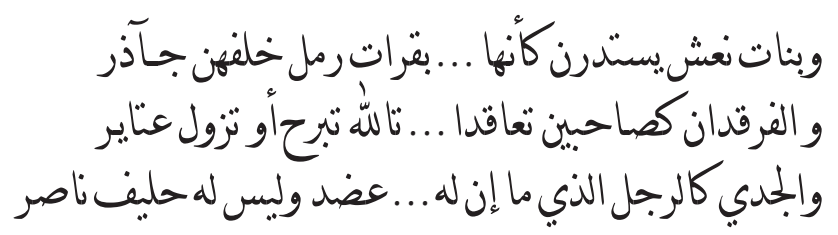

The stars of Ursa Major circle like addaxes followed by their new-born Ursa Minor stars are like two friends who vow that they will never leave each other

Capricorn is like a man without an arm who has no ally to defend him

Because we have no context, we cannot know why Ibn Harma chose these particular images or whether he originally placed them in an explanatory scheme. Astrology existed as an art among the Arabs and later Abbasid poets frequently referred to it in their poetry. ${ }^{38}$ However, these verses of Ibn Harma are unusual, as the vogue for astrological poetry had not yet become widespread.

Ibn Harma's attitude toward astrology — whether or not he believed in the influence of the constellations on people and nature - is not evident. The following example, however, shows that Ibn Harma's religious and cultural background sometimes influenced his poetic images. The poem draws from the Qurān where we read that spreading malicious slander is like eating the slandered person:39

1- $\quad$ Say to this two-faced man who is still consuming me: you think that you have won healthy meat

2- $\quad$ But I promise you that my tough skin will be a harness clamping jaws that will hurt you badly

3- $\quad$ That will be damaging your jaws; or may turn you into a sick animal covered in ticks and blood-sucking bugs

4- If someone's stupidity makes him rush towards me, ${ }^{40}$ becoming hornmad and unstoppable

38 For example Abū Tammām in his famous panegyric poem to al-Mu'tașim; see Badawi, Function of Rhetoric, 43-56.

39 Mu'aybid, Diwān, 214-215. See the Arabic original poem in Appendix 2. The eight lines of the Mu'aybid-edition appear as lines 10-17 of 18 lines in total sharing the same meter and rhyme in the Naffā' and 'Atwān- edition (207-11, 272). The Qur'ānic image is from Q 49:12 warning believers not to spy or gossip: "Do not back-bite one another. Would one of you love to eat the flesh of his dead brother" (transl. Pickthall).

40 Literally, "If someone's ostrich rushes towards me," a metonymy (kināya), metaphoric expression or a proverb meaning "He ran quickly"; see Iṣfahānī, Aghānī, IV, 265 (note by the editors); 'Askarī, Jamharat, I, 319; Naysābūrī, Majma', I, 239. Similarly, "His leather 
5- I will brand his neck so it would have an everlasting mark like the ring of the collared dove

6- I am a man; my hands do not fashion jewelry, but my tongue fashions fine speech

7- The hide that you were foolishly tanning is rotting and full of ticks

8- While the sign of a good skin is producing a sound when stretched and struck by tanners' hands

The central image of this poem is very powerful: while the slanderer may think that he will be sustained by healthy meat, he is in fact chewing tough skin that will damage his jaws or leave him drained of blood. The force is not only produced by the Qurānic image of eating the flesh, but also by the intensity and transformation of the original image by continuing to draw the consequences of the action in the further image of becoming ill and drained of blood. This transformation is also made in verses (4) and (5) which present an extraordinary comparison between two birds: the stupid, aggressive ostrich and the harmless, peaceful collared dove. The poet implies that he will make the ostrich as harmless as the dove.

Ibn Harma's employment of elements from his surrounding environment besides the sources of knowledge available to him helped him create his own context for the poetic image in a way which shows his advanced poetic skills. Not only is he employing the different elements of the image to function for one purpose, he also creates a positive and harmonious interaction between these elements. At the same time he succeeds in avoiding negative disagreement between the different elements of the image.

\section{Structure and Construction of Ibn Harma's Images}

In the above, we have surveyed the use of imagery in the poetry of Ibn Harma. The loss of the poet's original Dīwān enhances the risk of misjudging his surviving poetry, which is only available in fragmentary form, as we have noted. It is often not possible to determine the context of the image contained in the verses and inasmuch as the poems are undated guessing their contexts is restricted to a few exceptions, such as the panegyric to al-Manșūr we have seen above. What is possible, though, is an examination of partial isolated images found in the shorter pieces on the one hand, and on the other an analysis of

ropes (wadham) have been reinforced," meaning "He became full of anger"; see Ibn Manẓūr, Lisān, II, 895; Iṣfahānī, Aghānī, Hārūn edition, IV, 380 (note by the editors). 
a sequence of images in complete segments or longer fragments. So it seems appropriate to divide the images found in Ibn Harma's poetry into single and composite images and investigate how the poetic image as a whole is constructed - a subject to which we now turn. ${ }^{41}$

\section{Structure of Single Images}

In creating images Ibn Harma uses figurative devices, that is, simile and metaphor. That the poet is able to realize the similarities between his experiences on the one hand and the elements and objects of nature on the other, thus transforming the similarities into poetic images, is duly noted by Ahmad 'Alī Duhmān: "Ibn Harma has a great ability in depicting and realizing the relationships between similar and convergent images." 42

An illustration of Ibn Harma's ability to construct images can be gleaned from some single images based on figurative devices, as in: ${ }^{43}$

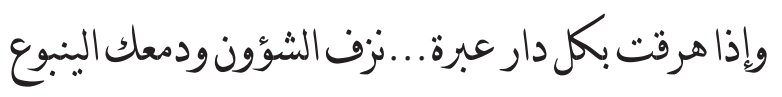

If you shed tears weeping in every encampment, your tear ducts and your tears that are (now) a fountain will dry up

The image in this verse is metaphorical: excessive weeping will end up blunting the emotions, so that tears will stop. Clearly the image is not meant to be taken literally, it is a cliché in classical Arabic poetry and it does not conform, for instance, to the fascinating comparison given by al-Jurjānī, renown literary theorist from the fifth/eleventh century. Al-Jurjānī remarks that the best image comes from comparing objects that are brought together from afar. As Abu Deeb cites al-Jurjānī:

... the images produced by the process of similarity ... are not appreciated... unless the similarity is between two things which belong to different species. Thus ... the further the distance (the difference) between the two objects is, the more fascinating to the soul (nafs) they are. ${ }^{44}$

\footnotetext{
41 Here we take our cue from Abū Șālih (Ibrāhìm b. Harma, 345) but he concentrates on the image's subject rather than the poetic image itself.

42 Duhmān, Ibrāhīm b. Harma, 82.

43 Mu'aybid, Diwān, 149.

44 Abu Deeb, Jurjānìs Theory, 68.
} 
In another example, Ibn Harma uses a single image to express emotions when in mourning for the death of Ibrāhīm al-Imām (d. 132/749), brother of the first Abbasid caliph al-Saffāḥ: ${ }^{45}$

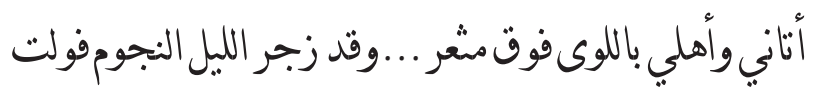

It came to my knowledge while I was with my family on Mathar after the night had chased the stars away

The image of the night's ending is based on a metaphor that depicts the imagination of the night chasing away the stars from the sky, then morning appears. The inventive imagination perhaps here conveys the poet's reaction to the messenger bringing bad news; the effect on the poet seems to be a mixture of sadness, anger and desperation.

This level of imagination extends to all parts of the poem which besides mourning over Ibrāhīm al-Imām also praises his brother, caliph al-Saffāh, for his mighty crushing of rebellions:

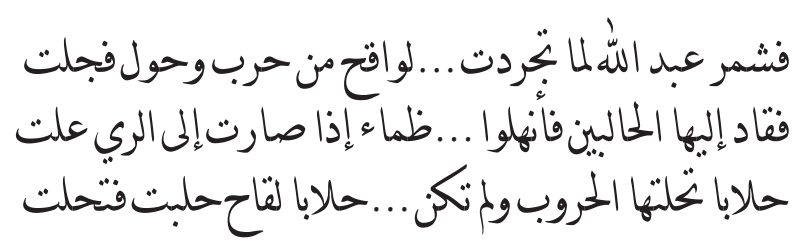

'Abdallah rolled up his sleeves when signs of pregnant and barren wars appeared

Then he led the milkers with their (swords), whose thirst, if they find the milk's source, they quench

With camels' sweet milk, this is sweetened by victories, not by the natural camels' pregnancy

The rebellions are metaphorically depicted as a group of she-camels likely to become a real danger, as they feed their rich milk to their offspring, swelling the number of their followers. 'Abdallah (al-Ṣaffāh) and his supporters are the camel-milkers whose swords will quench their thirst with the sweet milk of victory.

In the same poem, al-Saffāh is praised through the use of another figurative device, as in the following line: 46

\footnotetext{
45 Mu'aybid, Diwān, 69.

46 Ibid., 73 .
} 


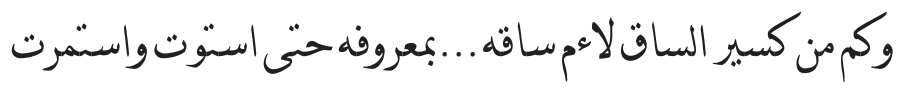

How many with a broken leg have you healed with your kindness until they are fully recovered?

The broken leg signifies the poverty that disables those who are disadvantaged in society; al-Saffāḥ's healing will bring them prosperity and opportunity. Images of this type are not very different from well-worn classical images, such as being of noble descent, as in: ${ }^{47}$

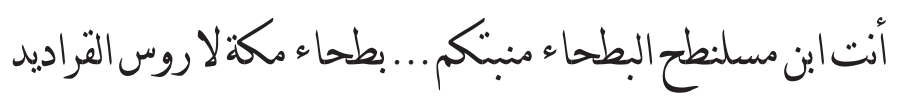

The soil where you grew up is the wide flat soil of Mecca not the harsh highlands

Similarly, the idea of a gift conveyed by the image of the patron's hand bestowing the reward, is a well known formula of classical panegyric: ${ }^{48}$

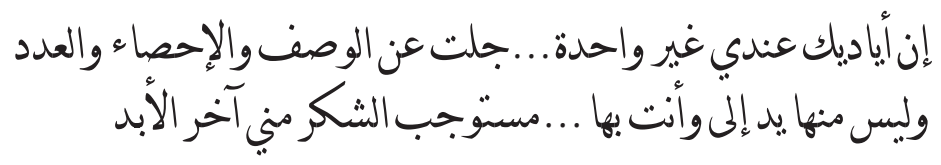

Your hands with me are not just one, they are uncountable and unspeakable

And for each one of them you are worthy of my interminable appreciations

Also the image of an arrow hitting a target indicating the ageing poet's insecurity shows little originality: 49

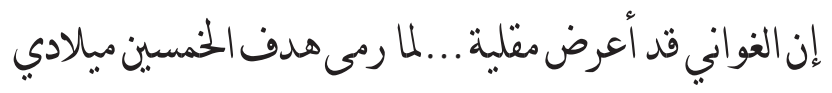

The beautiful girls have abandoned me now that my birthday has struck the target of fifty

On reaching the age of fifty, the poet finds himself no longer able to attract those he desires. The theme of the lover whose looks have faded is hardly a new one and the image is not striking enough to make a strong impression.

\begin{tabular}{ll}
\hline 47 & Ibid., 102. \\
48 & Ibid., 108. \\
49 & Ibid., 107.
\end{tabular}




\section{Structure of Composite Images}

Having discussed some of Ibn Harma's single images, we now turn to a study of his composite images, that is, a series of images used to construct a scene or a set of related ideas or impressions. A few of these composite images have already been discussed in the panegyric to al-Manșūr and the scene of featuring the dog, the host and the guest. In what follows, two fairly long fragments (of thirteen and nineteen verses) will be analyzed.

A composite image is an imagined picture which may be still or moving. It differs from the single image in several ways. First, the composite image comprises many elements that are organized and built in accordance with a clear conception determining the final shape of the entire image. Single images do not have such a function. Second, the single image is usually based on just one figurative device (simile or metaphor), while the composite image is based on a number of single images and other elements including non-figurative (literal) language. Third, the single image depicts a limited idea while the composite image depicts a whole scene or a set of ideas. As such, composite images require several verses at least, while the single image occupies only one or two verses.

To clarify the concept of composite images and the difference between single and composite images in Ibn Harma's poems, we now turn to an analysis of our first example, the poem of the Lizard and the Frog. The poem is based on a myth, as explained by al-Jăhiz (d. 255/869), thanks to whom the text survived: A flat-tailed lizard and a tailed frog compete in their abilities to refrain from drinking water and enduring the hardship of thirst. After three days, the frog succumbs and drinks, and the victorious lizard takes its tail. Ibn Harma imagines a dialogue between the two animals, employing a series of striking single images: ${ }^{50}$

1- Did you not lose sleep because of the flash of the thunderbolt in the darkness?

2- $\quad$ Like the necks of Indian women which are tainted with leprous marks?

$3^{-} \quad$ The gathering clouds are like reptiles moving slowly behind sick camels

4- $\quad$ The sounds are like the 'azif al-jinn, or wailing women ${ }^{51}$

50 Mu'aybid, Diwān, 89-90; Jāḥiz, Hayawān, vi, 126-127. See the original Arabic text in Appendix 3 .

51 The 'azif al-jinn is a common expression for the mysterious humming sounds sometimes heard in the desert and ascribed to the jinn. The humming sounds (or singing sands, whistling sands, or barking sands), are caused by friction or compression of air between the grains of sand, or by wind passing over sand dunes. 
5- On the clouds' white sides the light guides them as with a great torch

6- It was the time when the lizard said to the frog in a spacious desert

7- "Ponder how you will escape today from anguish and defeat

8- As I will survive by swimming while you are not a swimmer"

9- But when the cloud's nose was punched, the frog showed he could escape best

10- And the water poured down from a full udder

11- So, the lizard saw the frog's ineffective swimming

12- A heavily pouring cloud, not a light spray, brought down the mountain goats

13- Slow moving and like a drunken man walking followed by a sober

The build-up of single images in this poem has a clear function in constructing the strange, foreboding atmosphere of the whole scene. For example, the rather disturbing image of the lightning flash illuminating the darkness of the night is likened to the necks of Indian women tainted with leprous marks. The images contained in the next three verses seem to belong to a tale of the supernatural rather than a fable about rivalry between animals.

The scene-setting gives the encounter between the lizard and the frog an air of importance that would be absent in a straightforward narrative and seems to contradict the comical nature of the original story. Ibn Harma uses the fable as a starting point for the creation of a somber drama in which the apparent triviality of the original story is given weight by the extraordinary imagery. The feeling is that of a mock-heroic ode. It is a pity that only the above thirteen verses survived from what might have been a fascinating long poem. Here Ibn Harma seems to be writing for himself and his own circle, taking delight in his power of invention. It is remarkable how every image in the poem works towards creating the overall effect of the passage.

The tale of the lizard and the frog, just like the panegyric to al-Manșūr discussed above, reveal little of Ibn Harma's psychology. However, some of the poet's composite images that have survived from his panegyrics show very strong emotions. In a passage written for his former patron, Ibn Harma writes candidly about their relationship leaving the reader feel this to be a personal letter between estranged friends, not a conventional praise poem for public consumption.

Ibn Harma wrote the poem when his patron, 'Abd al-Wāhid b. Sulaymān, son of caliph 'Abd al-Malik, was angry with him for praising another patron. The poet spends twelve verses describing his feelings and apologizing for his conduct and only seven verses are devoted to praise. All have a personal quality and are not simply formulaic — as they are in the poem composed for 
al-Manșūr. Even the last four verses which do have a formulaic quality seem to be genuinely felt.

The poem is likely to be a fragment and we do not know what the lost part of the poem may have contained. What has survived seems a complete section from which nothing vital is missing. It presents the interaction between images of the poet and the patron, particularly in verses (13-15). Here is the fragment in full: ${ }^{2}$

1- You have destroyed the bonds of Salmā's love for the sake of the love of Hind, so you will not find repose

2- $\quad$ For if you stay you would not meet Hind, and if you leave your heart will not forget

3- As it will spend the day in delirium for Hind, and the night it will be sleepless till dawn

4- O praiseworthy 'Abd al-Wāḥid, I am choking, not able to gulp even water, fearful of your wrath

$5^{-} \quad$ May my hands wane, and may my horse throw me into a tree of lances

6- And may I be disabled by time, and my hands empty of all my wealth, both near and far

$7^{-}$If I sing someone else's glory in my praise, tribute, and recommendation while away from you

8- My poems will be like noble ladies who are prohibited to marry, so make me a favorite of yours' and prevent me from turning to another

9- As even if I have erred with a prince, it was an accident beyond my will

10- It was just a blunder for which we have been condemned, but some of the things people say are blown away by the wind

11- I swear that not only I, but all the sons of 'Adī, and whoever wishes me well

12- If you were not pleased with me and did not reward me, I would suffer an enduring desolation

13- And you are, as when I came to you in the west of al-Sharāt, a generous man

14- You jovially granted one request and promised another, and you did not stint on the first

15- You have guarded your place in a privileged part of my heart, and your place is unreachable by others

$5^{2} \quad$ Mu'aybid, Diwān, 84-87. See the original Arabic text in Appendix 4. 
16- We found that Ghālib ${ }^{53}$ were created as a wing, but your father was their covering feather

17- You are artful when hunted, and you are far from men's vituperation

18- While the miser makes stinginess his shield and his favorite weapon

19- Your armament is kindness, which enables you to win a virtuous and faultless character

The poem begins with a brief classical nasib; the love imagery may allude to Ibn Harma's relationships with 'Abd al-Wāhid (Salmā) and his other patron who has dismissed him (Hind). The poet then turns to depict his fear of 'Abd al-Wāhid's anger and its consequences and goes on to protest his loyalty; his sojourn with the other patron was a mistake for which he has been punished. If he does not praise 'Abdul-Wāhid, his poems will be like ladies doomed to a fruitless existence.

The single images of the poem are powerful: the delirium, the choking, the numbness, the tree of lances. The tone is generally not that of a servant seeking reinstatement, the poet rather appears as an erring lover seeking forgiveness for his infidelity. He insists that his straying was an accident and the patron/ lover has a place in a privileged part of his heart that others cannot penetrate. Such intensity of feelings typical of lovers was hitherto unusual in a classical Arabic panegyric for a patron. It would take another century and a half before the even more intense emotions between the famous poet al-Mutanabbī (d. 354/955) and his patron Sayf al-Dawla would be voiced.

\section{Ibn Harma's Method of Constructing Images}

The process of constructing poetic images is convoluted. A host of inherited and well imbedded images amalgamate together with the poets' own images to project a personal imagination which may differ greatly from that of other poets or from inherited images. Such new images may have a risky outcome; the poet may totally fascinate his listeners but can be shocking as well. A poet's ability to create new images that are well received determines to a degree his success and place among their peers.

The fragment of a probably longer poem, that we will now discuss, shows that Ibn Harma was indeed innovative to such degree. The fragment seems, just like the previous one, complete in itself. Ibn Harma carefully builds an extended metaphor which identifies his poems with camels and compares his

53 Ghālib (b. Fihr b. Mālik b. al-Naḍr b. Kināna) is the progenitor of the Banū Quraysh from which the patron descends. Hence the translation "Ghālib were" in the plural following the Arabic original. 
peers with thieves. They plagiarize his work just like thieves steal camels to improve their stock, without acknowledging any debts. A series of similes precede the metaphor, as follows: ${ }^{54}$

1- I raised some ancient poetry to improve it as a wise man would improve his good things

2- I invent memorable lasting poems for those who recite poetry, so they see them as embroidered mantles

$3^{-} \quad$ Be they love-poetry, or praise for an honorable man, to immortalize him or defend him from dim-witted people

4- But when those who recite are so amazed that their ears and hearts are filled as they find (my poems) sweet as honey

$5^{-} \quad$ They begin stealing my camels and moving them to their pastures to impregnate their females

6- Then, they botch up hobbles for the camels which are too loose, and so do not restrain the camel as it walks

7- Whereas I have no part in the impregnation, nor do I share the pastures, be they in a plain or on a mountain top

8- But then still I know my mark, which I have put (on my camels), once I see it in another man's camels herd

9- If I ever put a mark on camels before they go to pasture they will return to me despite their hobbles

The poet's use of an extended metaphor is of a high level of sophistication. The passage begins by describing the excellence of Ibn Harma's poems, making other poets so envious that they want to steal them. In a series of similes, Ibn Harma likens himself to a wise man improving something good. His poems are praised for being "memorable, lasting" and the poet hopes for himself to be remembered forever through his poetry appearing like embroidered mantles and sweet as honey to those who recite them. It is noteworthy that Ibn Harma speaks of himself as a conservative who innovates within limits, preserving and improving what is good rather than seeking to achieve a radical change.

The poet subsequently contrasts his own verse/camels with those of the thieves. Every verse contributes to this composite image and everything is so well handled that the identification does not seem to be forced. The thieves steal Ibn Harma's camels that are of a noble breed to impregnate their own she-camels. Significantly, it is Ibn Harma's camels that are male, and have the capability of fertilizing the poor stock of the poet's imitators. The difference

54 Mu'aybid, Diwān, 184-185. See the original Arabic text in Appendix 5. 
between his own herd and that of the thieves is so obvious, that even a single line bearing his mark is easily recognized among a crowd of verses composed by the plagiarists. They simply lack the skill of creating composite images that stand out (they cannot adequately hobble Ibn Harma's camels).

\section{Conclusion}

It has generally been assumed that the Umayyad/early Abbasid poet Ibn Harma was appreciated first and foremost for his use of "pure" Arabic and as such he was reckoned among the classical Arabic poets. In our investigation of Ibn Harma's surviving poetry, we have focused on the poet's use of imagery. We have done so from two angles, one a study of subject matter, the other an analysis of how imagery was constructed.

The loss of the poet's complete Diwān makes it hard to appreciate his images - especially single images found in one isolated verse or a pair of verses since their context is missing. But even from such short fragments, Ibn Harma's ability to create similes in particular and realize similarities even in dissimilar objects becomes evident. Some of the longer fragments that survived allow for an analysis of composite images, though restricted since these fragments are still part of longer poems that are not extant in full.

As we have seen, the great quality of diverse images Ibn Harma created shows that the poet regarded imagery as crucial for his achievements, the creation of images his chief asset. The employment of different elements from nature, human experience, and knowledge often functions in Ibn Harma's imagery to construct a self-image. These self-images present the poet as a role model, depicting his many virtues and praising his poetic abilities and the excellence of his poetry. The images of other people in Ibn Harma's poetry are limited to beloved women and worthy patrons. Images furthermore include animals, scenery, and stars.

In view of the fragmentary nature of Ibn Harma's surviving poetry, any judgment about his status and the quality of his work should be made with caution. Our study of the poet's imagery nevertheless allows for some conclusions.

Ibn Harma was a classical poet in the sense that he was a professional composing panegyrics for money. He was well aware of the rivalrous environment of which he was part and of the requirements prospective patrons imposed on him. Ibn Harma's poetry was classical in the sense that he used common themes from Arabic culture and followed the structure and style of the traditional qașida. However, although some of his single images in particular are not at all that novel, the imagery found in the longer fragments is of high quality and 
innovative nature - the central element of the muhdath project. Especially when the poet's personal emotions find their way into his work, strong and powerful images are expressed. His choice of style and force of language set him apart as an independent creative individual capable of innovation within a traditional framework. As such, we see Ibn Harma positioned amongst the rearguard of the classical poets at the threshold of Abbasid modernity.

\section{Appendixes}

\section{Appendix 1}

$$
\begin{aligned}
& \text { 1- - سرى ثوبه عنك الصبا المتخايل ...وودو للمين الخلبط المزايل }
\end{aligned}
$$

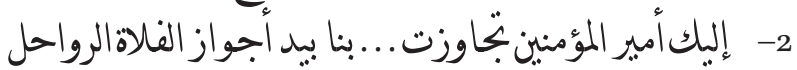

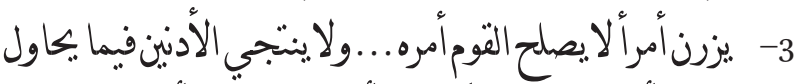

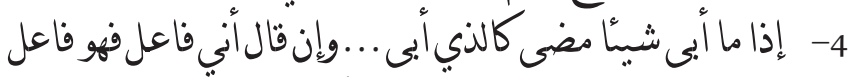

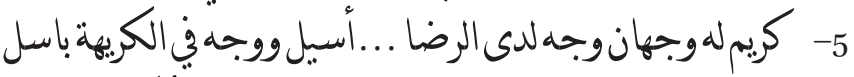

$$
\begin{aligned}
& \text { 6- ولبس بمعطي العفو عن غير قدرة ... وبعفو إذا ما أمكنته المقاتل }
\end{aligned}
$$

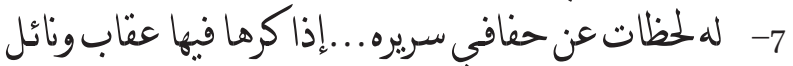

$$
\begin{aligned}
& \text { 8- فأم الذي أمنت آمنة:الردى ....وأم الذي حاولت بالثنكل ثاكل }
\end{aligned}
$$

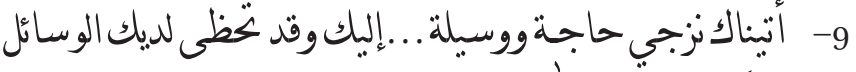

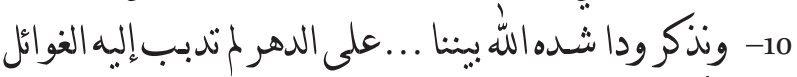

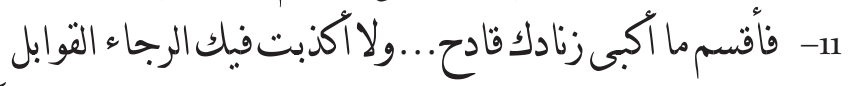

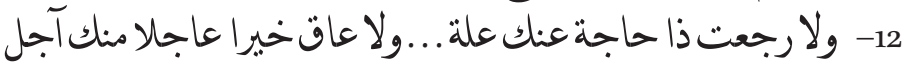

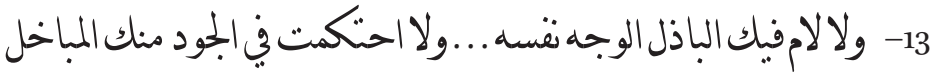

$$
\begin{aligned}
& \text { 14- لهم طينة بيضاء من آل هاشم ...إذا اسود من لؤم الزّاب القبائل }
\end{aligned}
$$

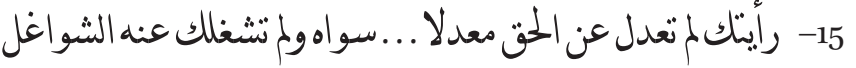

Appendix 2

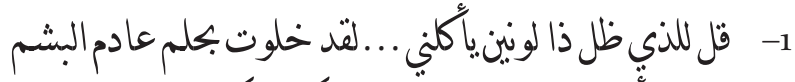

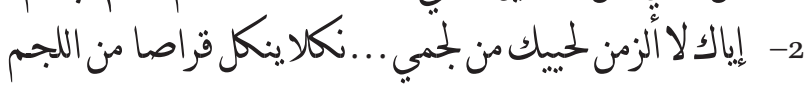


3- يدق لحبيك أو تنقاد متبعا ....مشي المتيد ذي القردانوالحلم

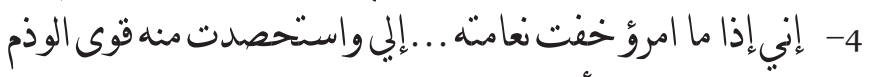

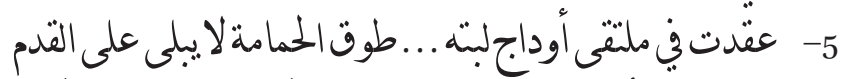

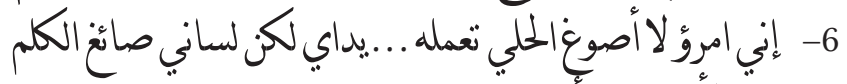

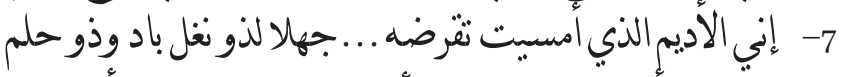

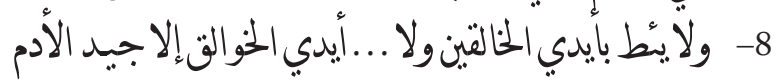

Appendix 3

$$
\begin{aligned}
& \text { 1- ألمانأرق لضوء البر ....ق في أسحملماح } \\
& \text { 2- كاعناق نساء المند ... فد شيست بأوضعاح }
\end{aligned}
$$

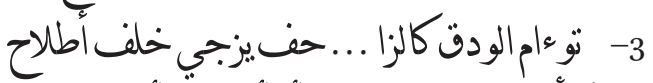

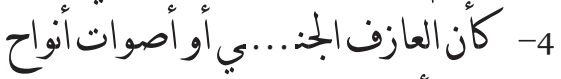

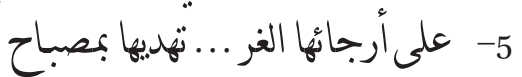

$$
\begin{aligned}
& \text { 6- فنال الضب للضفي....دعوني بيداء فرواح }
\end{aligned}
$$

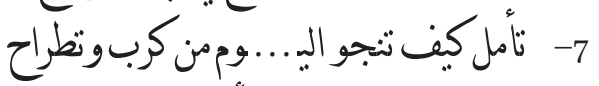

$$
\begin{aligned}
& \text { 8- فاني سابح ناج....وما أنت بسبـاح } \\
& \text { 9- فلما دق أنف المز .... ن أبدى خير إرواح } \\
& \text { 10- وسح الماء من سستح ....لب بالماء سحاح } \\
& \text { 11- راى الضب من الضف.... دوعوما غير منجاح } \\
& \text { 12- وحط العصم.يهوبيها ... ثجوججير نشاح } \\
& \text { 13- ثقال المشي كالسكران ... يمشي خلفه الصاحي }
\end{aligned}
$$

Appendix 4

1- صرمت حبائلا من حب سلمى ... لهند ما عمدت لمستراح

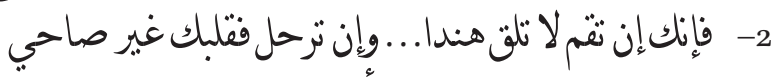

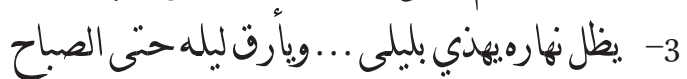

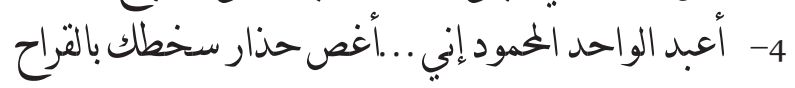




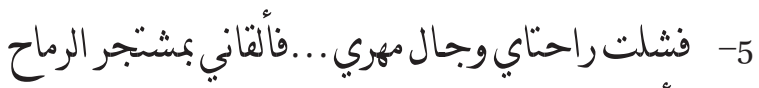

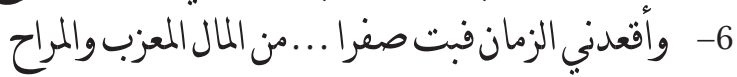

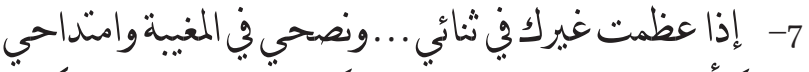

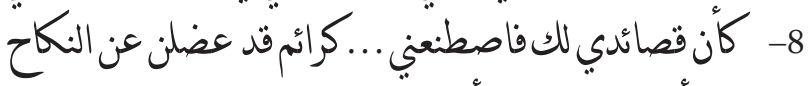
9- فإن أك قد هفوت إلى أمير ....فعن غير التطوع والسماح 10- ولكن سفطة عيبت علينا ... وبعض القول يذهب في الرياح

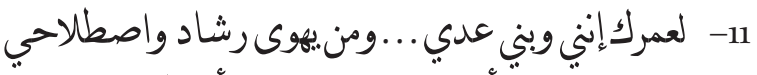
12- إذا لم ترض عنئي أو تصلني ...لفي حبن أعالجهمتناح

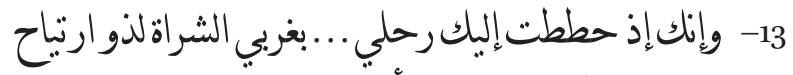
14- هششت لحاجة ووعدت أخرى ...ولم نبخل بناجزة السراح

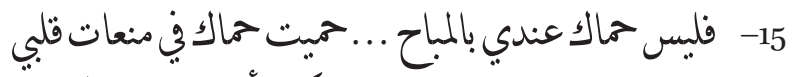

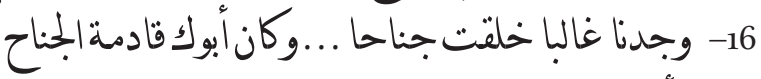

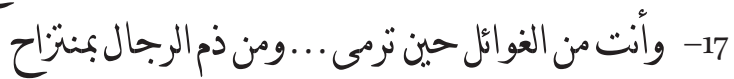

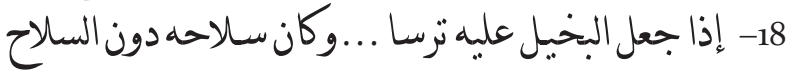

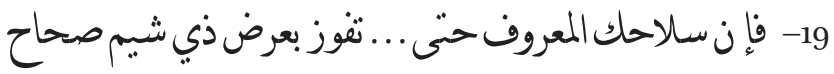

\section{Appendix 5}

1- أغذو تلادا من الأشعار أصلحها ... صلاحذي الحزم للحاجاتوالرتل

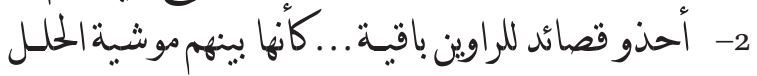

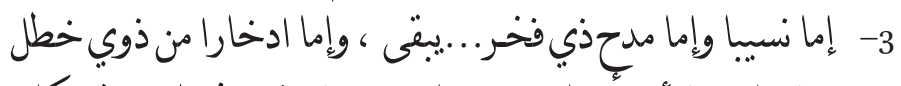

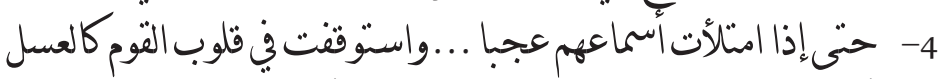

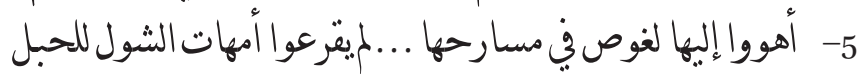

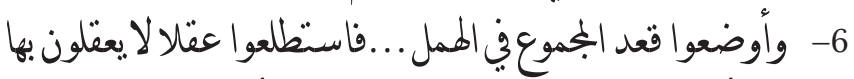

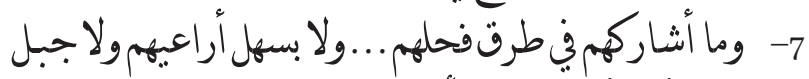

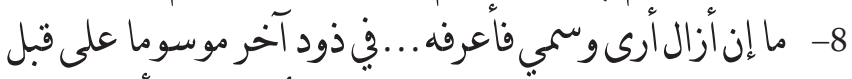
9- وما وسمت فلاصا وهي رانعة ...حتى أنت رغم الأقياد والعقل 


\section{References}

\section{Primary Sources}

Al-'Askarī, Abū Hilāl al-Ḥasan b. 'Abdallāh, Jamharat al-amthāl, vol.ı, ed. by Aḥmad 'Abd al-Salām and Muhammad Sa'̄id Zaghlūl Basyūnī, Beirut: Dār al-Kutub al-'Ilmiyya, 1988

Al-Buhturūi, Abū 'Ubāda al-Walīd b. 'Ubayd, al-Ḥamāsa, Book 1, ed. by Kamāl Mustafā, Cairo: al-Mațba'a al-Raḥmāniyya, 1929

Ibn Qutayba, Abū Muhammad 'Abdallāh b. Muslim al-Dīnawarī al-Marwazī, Al-Shi'r wa-l-shu'arā', ed. by Aḥmad Shākir, 2 vols., Cairo: Dār al-Ma'ārif, 1982

Ibn 'Abd Rabbih, Aḥmad b. Muhạmmad, al-'Iqd al-Farìd, 7 vols., Beirut: Dār Iḥyā' al-Turāth al-'Arabī, 1999

Ibn Manẓūr, Muḥammad b. Mukarram, Lisān al-'Arab, ed. by 'Abdallāh 'Alī al-Kabīr, Muḥammad Aḥmad Ḥasab Allāh and Hāshim Muḥammad al-Shādhilī, 6 vols., Cairo: Dār al-Ma'ārif, 1981

Al-Iṣfahānī, Abū l-Faraj, Kitāa al-Aghānī, ed. by Iḥsān 'Abbās, Bakr 'Abbās and Ibrāhīm al-Sa‘āīn, 25 vols., Beirut: Dār Ṣādir, 2008; ed. by ‘Abd al-Salām Muhammad Hārūn, 24 vols., Cairo: Mațba'at Dār al-Kutub al-Mișriyya, 1927

Al-Jāḥiz, Abū 'Uthmān 'Amr b. Baḥr, al-Bayān wa-l-tabyīn, ed. by Darwīsh Juwayda, Beirut: al-Maktaba al-'Așriyya, 1999

—_, al-Hayawān, ed. by 'Abd al-Salām Muḥammad Hārūn, 8 vols., Cairo: Sharikat wa-Mațba'at Mușțafā al-Bābī al-Ḥalabī wa-Awlādih, 1965

Al-Marzūqī, Ibn 'Ali al-Isfahānī, Kitāb al-Azmina wa-l-amkina, ed. by Khalīl al-Manșūr, Beirut: Dār al-Kutub al-'Ilmiyya, 1996

Al-Naysābūrī, Aḥmad b. Muḥammad al-Maydānī, Majmac al-amthāl, Vol. I, ed. by Muḥammad Muḥȳ̄ al-Dīn 'Abd al-Ḥamīd, Cairo: Mațba'at al-Sunna al-Muhammadiyya, 1955

al-Suyūṭ̂, Jalāl al-Dīn, Sharh shawāhid al-Mughnī, ed. by Muḥammad Maḥmūd al-Shinqīṭī, Cairo: al-Mațba'a al-Bahiyya, 1904

\section{Secondary Sources}

Al-Abbasi, Abeer Abdullah A., Astrology in Literature: How the Prohibited Became Permissible in the Arabic poetry of the Medieval Period, PhD thesis, Leeds University, Leeds 2008

'Abd al-Raḥmān, Nuṣrat, Al-Ṣūra al-fanniya fì l-shi'r al-jāhilì fì daw' al-naqd al-ḥadīth, Amman: Maktabat al-Aqșā, 1976

Abu Deeb, Kamāl, Al-Jurjānı’s Theory of Poetic Imagery, Warminster: Aris and Phillips, 1979 Abu-Khadra, Fahid, Ellipsis in the 2nd Century A.H., in: Arabica 33 (1986), 76-83

Abū Ṣāliḥ, Shādin 'Abd al-Quddūs, Ibrāhīm b. Harma: Hayātuh wa-shi'ruh, MA thesis, al-Dammam Girls' College, Saudi Arabia, 1989 
Annas, Pamela , A Poetry of Survival: Unnaming and Renaming in the Poetry of Audre Lorde, Pat Parker, Sylvia Plath, and Adrienne Rich, in: Colby Library Quarterly 18/1 (1982), 9-15

'Awaḍ, Rītā, Binyat al-qașīda al-Jāhiliya, Beirut: Dār al-Ādāb, 1992

Badawi, M. M., The Function of Rhetoric in Medieval Arabic Poetry: Abū Tammām's Ode on Amorium, in:Journal of Arabic Literature 9 (1978), 43-56

Bashīr, 'Abdul-'Ālī, Șūrat al-nāqa fì l-nașṣ al-jāhilī, in: Majallat al-Turāth al-'Arab̄̄ 101 (2006); http://www.awu-dam.org/trath/101/Turāth101-016.htm [accessed 28 December 2014]

Blachère, Régis, Histoire de la littérature arabe des origines à la fin du XVe siècle de J.-C., Paris: Librairie d'Amérique et d'Orient, $195^{2}$

Duhmān, Aḥmad 'Ali, Ibrāhīm b. Harma: Khātimat al-shu'arā’ al-qudamā’ wa-bidāyat al-muḥdathīn, in: Majallat al-Turāth al-Arabī 93-94 (2004); http://www.awu-dam. org/trath/93-94/Turāth93-94-008.htm [accessed on 1 January 2015]

Heinrichs, Wolfhart, Paired Metaphor in Muhdath Poetry, in: Occasional Papers of the School of Abbasid Studies 1 (1986), 1-22

Jacobi, Renate, The Camel-Section of the Panegyrical Ode, in: Journal of Arabic Literature $13 / 1$ (1982), 1-22

Jacobi, Renate, The "Khayāl" Motif in Early Arabic Poetry, in: Oriens 32 (1990), 50-64

Jabal, Muhammad Hasan, Al-Iḥtijāj bi-l-shi'r fì l-lugha: Al-Wāqi` wa-dalālātuh, Cairo: Dār al-Fikr al-'Arabī, n.d.

Meisami, Julie Scott and Paul Starkey (eds.), Encyclopedia of Arabic Literature, New York: Routledge, 1998

Al-Mu'aybid, Muḥammad Jabbār, Diwān Ibrāhīm b. Harma, al-Najaf: Maṭba'at al-Ādāb, 1969

Naffā', Muḥammad and Ḥusayn 'Ațwān, Shi'r Ibn Harma, Ibrāhīm b. Alī al-Qurashī, Damascus: Majma' al-Lugha al-'Arabiyya fì Dimashq, 1969

Pellat Charles, Ibn Harma, in: Encyclopaedia of Islam, Second Edition, 13 vols., Leiden: Brill, 1954-2005, III, 786

Pickthall, Marmaduke, The Meaning of the Glorious Qur'an: An Explanatory Translation, New York: Alfred A. Knopf, 1930

Qāsim, 'Adnān Ḥusayn, Al-Tașwìr al-shi'rī: Ru'ya naqdiyya li-balāghatinā al-'Arabiyya, Cairo: Maktabat al-Falāḥ, n.d.

Salhi, Zahia Smail and Abeer Abdullah Al-Abbasi, Astrology between Poetics and Politics in the Abbasid Period: Abu al-'Alā' al-Ma'arri as Case Study, in:Journal of Semitic Studies 57/2 (2012), 347-401

Sells, Michael, Guises of the Ghūl: Dissembling Simile and Semantic Flow in the Classical Arabic Nasīb, in: Suzanne Stetkevych (ed.), Reorientations: Arabic and Persian Poetry, Bloomsbury: Indiana University Press, 1994

Sezgin, Fuat, Geschichte des Arabischen Schrifttums Band II: Poesie. Bis ca. 430 H, Leiden: Brill, 1996 
Stetkevych, Jaroslav, Zephyrs of Najd: The Poetics of Nostalgia in the Classical Arabic Nasīb, Chicago: University of Chicago Press, 1993

Stetkevych, Suzanne Pinckney (ed.), Early Islamic Poetry and Poetics, Surrey: Ashgate, 2009

(ed.), Reorientations: Arabic and Persian Poetry, Bloomington: Indiana University Press, 1994

Toorawa, Shawkat M., Ibn Harma al-Qurashī, in: Julie Scott Meisami and Paul Starkey (eds.), Encyclopaedia of Arabic Literature, London/New York: Routledge, 1998, I, 331

'Ușfūr, Jābir, Al-Ṣūra al-fanniyya fì l-turāth al-naqdī wa-l-balāghì 'inda l-Arab, Beirut: al-Markaz al-Thaqāfī al-'Arabī, 1993 